\title{
構造信頼性解析における 3 次モーメント信頼性指標の検討 AN INVESTIGATION ON THIRD-MOMENT RELIABILITY INDICES FOR STRUCTURAL RELIABILITY ANALYSIS
}

\author{
趙 衍 剛*, 小野徹郎** \\ Yan-Gang ZHAO and Tetsuro ONO
}

\begin{abstract}
Moment methods have been developed to avoid the difficulties involved in searching the design point by iteration using the derivatives of the performance function, a principle shortcoming of reliability methods based on the first-order reliability method (FORM). In order to investigate the accuracy, efficiency and applicability of moment methods, in the present paper, several third- moment reliability indices are presented, investigated and compared. Through the investigations, a simple third- moment reliability index is suggested for moment methods. It is found that the third-moment reliability index has sufficient accuracy and it is convenient to be applied to structural reliability analysis.
\end{abstract}

Keywords: structural reliability, performance function, FORM, third-moment method, fourth-moment method 構造信頼性、限界状態関数、 1 次信頼性近似、3 次モーメント法、4 次モーメント法

1.はじめに

構造信頼性理論では、破壊確率を効率よく計算するために、様々な 近似法が考えられ、その中でも一次信頼性解析法(FORM)は、構造信 頼性解析の一般的な手法として認識されている川11 。ORM信頼性指標 は $u$ 空間における原点から限界状態曲面への最短距離として定義さ れ、その問題点は、限界状態関数の導関数を求めなければならないと か、設計点を求める時の局部収束、設計点における線形近似の精度な どにある|2|。FORMの問題点を改善するために多くの手法が提案され たが、設計点に関わる問題は線形計画法を用いる繰返し計算の固有な 問題点であり, 改善することは難しい。FORM設計点問題を回避する ために、限界状態関数の確率モーメントを利用して破壊確率を計算す るモ一メント法を提案してきた ${ }^{21}$ 。限界状態関数の分布形はそのモ一 メントと直接関係があり、その関係を簡便に表せば, 信頼性指標また は破壊確率も簡単に計算できる。

モーメント法では設計点の概念を用いず、繰り返し計算、導関数及 び設計点に係わる問題点がないが、適切なモーメント信頼性指標を設 定する必要がある。モーメント信頼性指標についてはいくつかの 3 、 4 次モーメント信頼性指標を考察し12、結果的に式(1)の3 次モ一メ ント信頼性指標（TM信頼性指標）と式(2)の 4 次モーメント信頼性指 標（FM 信頼性指標）を提示してきた。

$$
\begin{gathered}
\beta_{T M}=\beta_{S M}+\frac{1}{6} \alpha_{3 G}\left(\beta_{S M}^{2}-1\right) \\
\beta_{F M}=\frac{3\left(\alpha_{4 G}-1\right) \beta_{S M}+\alpha_{3 G}\left(\beta_{S M}^{2}-1\right)}{\sqrt{\left(9 \alpha_{4 G}-5 \alpha_{3 G}^{2}-9\right)\left(\alpha_{4 G}-1\right)}}
\end{gathered}
$$

ただし、 $\beta_{s M}$ は 2 次モーメント信頼性指標（SM 信頼性指標）であり、 次式で表される。

$$
\beta_{S M}=\frac{\mu_{G}}{\sigma_{G}}
$$

$\mu_{G}, \sigma_{G}$ は、それぞれ限界状態関数 $\mathrm{Z}=G(\mathbf{X})$ の平均值、標準偏差である。 $\alpha_{3 G}, \alpha_{4 G}$ は $\mathrm{Z}=G(\mathbf{X})$ の無次元 3、4 次モーメントであり、それぞれ分布 形の歪度 (skewness) と尖度 (kurtosis) を表している。

以下の検討では式(1)を TM-1 信頼性指標といい、式(2)を FM 信頼 性指標という。

式(2)のFM信頼性指標は小野・井戸田の高次積率標準化手法(HOM $\mathrm{ST})^{[3|14|}$ を用いた 3 次モーメント標準化関数 ${ }^{21}$ に基づいている。この FM 信頼性指標の適応性はすでに検討されているが、3次モ一メント 標準化という原則に基づく割に、限界状態関数の 4 次までのモーメン トを用いなければならないことに不満が残る。
* 名古屋工業大学 助教授. 工博

** 名古屋工業大学 教授·工博 
式(1)のTM信頼性指標は、 $\alpha_{3 G}$ の絶対値が十分小さい時、限界状態 関数の非正規性が強くないと仮定して式(2)のFM 信頼性指標から導 いたものである。式(1)は、限界状態関数の 3 次までのモーメントの みを用いており、形式上かなり簡潔であるが、限界状態関数の非正 規性が強くないことが前提となる。

そこで本論文では、できる限り少ないモーメント情報を用いるとい う視点から 3 次モーメント法に着目し、いくつかのTM信頼性指標を 提示して、その精度、適用性などにおける問題点を明らかにすること を目的とする。

\section{TM 信頼性指摽}

3 次モーメント法を考察するために、本節では既存のTM信頼性指 標として、宇賀田のTM信頼性指標を示すとともに、新たにいくつか の 3 次モーメント信頼性指標を提示する。

\section{1 宇賀田の TM 信頼性指標}

対数正規分布、指数分布等、一般に理論分布として知られている分 布の形状は歪み具合や尖り具合は違うものの、いわゆる釣鐘型をして いる。そこで、宇賀田浜はこの共通点に着目し、対数正規分布の非超 過確率と歪度 $\alpha_{3 G}$ の関倸を一般化することにより：限界状態関数 $Z=G(\mathbf{X})$ の標準化確率変数

$$
x_{s}=\frac{Z-\mu_{G}}{\sigma_{G}}
$$

と標準正規確率変数 $u$ の関係を次のように与えている(5)。

$$
u=\frac{\zeta}{2}+\frac{\ln \left[1+\operatorname{sign}\left(\alpha_{3 G}\right) x_{s} \sqrt{\exp \left(\zeta^{2}\right)-1}\right]}{\zeta}
$$

ただし、

$$
\begin{aligned}
& \zeta=\operatorname{sign}\left(\alpha_{3 G}\right)\left\{\ln \left[\left(\frac{\eta}{2}\right)^{2 / 3}+\left(\frac{2}{\eta}\right)^{2 / 3}-1\right]\right\}^{\frac{1}{2}} \\
& \eta=\alpha_{3 G}+\sqrt{\alpha_{3 G}^{2}+4}
\end{aligned}
$$

式 (6) は少々複雑であるので、次の近似式により

$$
\zeta=a \tan ^{-1}\left(\alpha_{3 G}\right)
$$

ただし、aは未定倸数であり、対象分布形によって定められ、いまま での文献では $a=1 / 3^{|5|}$ まは $a=1 / 2^{|6|}$ として検討されている。以下の検 討では特別な場合を除き、 $a=1 / 3$ とする。

式(5)は次式により簡単に表される。

$$
u=\frac{\zeta}{2}+\frac{\ln \left[1+x_{s} \zeta\right]}{\zeta}
$$

式 (9) より、宇賀田は次式の TM 信頼性指標を提案している|5|。

$$
\beta_{T M}=-\frac{\zeta}{2}-\frac{\ln \left[1-\beta_{S M} \zeta\right]}{\zeta}
$$

以下の検討では式(10) を TM-2 信頼性指標という。 式(10)では、 $\alpha_{3 G}$ が0に近付く時、らも0に近付き、TM-1 信頼性指 標はSM 信頼性指標に近付くことになる。

$$
\lim _{3 G \rightarrow 0} \beta_{T M}=\beta_{S M}
$$

TM-2 信頼性指標の適用範囲について、文献[5]では言及されていな いが、文献[5]の $\zeta-\alpha_{3}$ 図により、 $\left|\alpha_{3 G}\right|>1$ のとき式(8)の近似式を用い た結果と正解值の間の隔たりが明らかとなり、TM-2 信頼性指標の適 用範囲は $\left|\alpha_{3 G}\right|<1$ であると考えられる。また、 $\left|\alpha_{3 G}\right|$ が十分小さい時、 対数関数の級数展開から式(10)を式(1)のように展開することができ る。即ち、| $\left|\alpha_{3 G}\right|$ が十分小さい時、TM-2 信頼性指標は TM-1 信頼性指 標の形式になる。

\subsection{Tichy の FOTMによる 3 次モーメント信頼性指標}

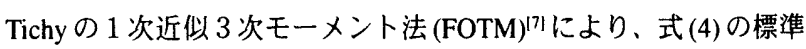
化確率変数に対して $u=\ln \left|x_{s}-u_{b}\right|$ が正規確率変数であれば、 $x$ は $3 つ$ のパラメータを有する対数正規確率変数である。ただし、 $u_{b}$ は標潐化 境界を表す。この分布によって $x_{s}$ とuについては次の関係がある ${ }^{|8|} 。$

$$
u=\frac{\operatorname{sign}\left(\alpha_{3 G}\right)}{\sqrt{\ln (A)}} \ln \left[\sqrt{A}\left(1-\frac{x_{s}}{u_{b}}\right)\right]
$$

ただし、

$$
A=1+\frac{1}{u_{b}^{2}}
$$

標準化境界 $u_{b}$ は次の 3 次方程式を満足する。

$$
\alpha_{3 G} u_{b}^{3}+3 u_{b}^{2}+1=0
$$

式(14)より、

$$
\begin{aligned}
& u_{b}=(a+b)^{\frac{1}{3}}+(a-b)^{\frac{1}{3}}-\frac{1}{\alpha_{3 G}} \\
& a=-\frac{1}{\alpha_{3 G}}\left(\frac{1}{\alpha_{3 G}^{2}}+\frac{1}{2}\right), \quad b=\frac{1}{2 \alpha_{3 G}^{2}} \sqrt{\alpha_{3 G}^{2}+4}
\end{aligned}
$$

式(12)より、TM 信頼性指標は次のように得られる。

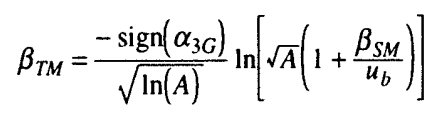

付録に示すように式(5)と式(12)は同じ 3 つのパラメータを持つ対 数正規分布の標準正規化変換の異なる表現形式であり、それらに基づ く TM 信頼性指標も原則的に同じである。また、式(17)のTM信頼性 指標はやや煩雑であり、応用上が不便なので、本論文の検討対象とし ない。

\subsection{3 次モーメント標準化に基いた TM 信頼性指摽の提示}

式(2)の FM 信頼性指標は次式の 3 次モーメント標準化関数の近似 式から得られている(2)。

$$
u=\frac{\alpha_{3 G}+3\left(\alpha_{4 G}-1\right) x_{s}-\alpha_{3 G} x_{s}^{2}}{\sqrt{\left(9 \alpha_{4 G}-5 \alpha_{3 G}^{2}-9\right)\left(\alpha_{4 G}-1\right)}}
$$

式 (18) は 3 次モーメント標準化関数の近似式であるものの、4 次 モーメントを用いなければならない。4 次モーメントを用いることを 回避するために、次の厳密な 3 次モーメント標準化関数の逆関数が提 案されている19!。

$$
x_{s}=-\lambda+\sqrt{1-2 \lambda^{2}} u+\lambda u^{2}
$$


ただし、

$$
\lambda=\operatorname{Sign}\left(\alpha_{3}\right) \sqrt{2} \cos \left[\frac{\pi+|\theta|}{3}\right], \quad \theta=\tan ^{-1}\left(\frac{\sqrt{8-\alpha_{3 G}^{2}}}{\alpha_{3 G}}\right)
$$

さらに、 $\left|\alpha_{36}\right|<1$ の時、式(20)を式(21)の簡単な式で精度よく（誤差 2\%以下）近似することができ!10、3 次モーメント慗準化関数の逆関 数は式(22)のように簡単に表される。

$$
\begin{aligned}
& \lambda=\frac{1}{6} \alpha_{3 G} \\
& x_{s}=-\frac{1}{6} \alpha_{3 G}+u+\frac{1}{6} \alpha_{3 G} u^{2}
\end{aligned}
$$

式(22)により、3次モーメント標準化関数は次のように得られる。

$$
u=\frac{1}{\alpha_{3}}\left(\sqrt{9+\alpha_{3}^{2}+6 \alpha_{3} x_{s}}-3\right)
$$

式(23)により、TM 信頼性指標は次のように得られる。

$$
\beta_{T M}=\frac{1}{\alpha_{3 G}}\left(3-\sqrt{9+\alpha_{3 G}^{2}-6 \alpha_{3 G} \beta_{S M}}\right)
$$

以下の検討では式 (24)を TM-3 信頼性指標という。

TM-3 信頼性指標は 3 次までのモーメントのみ用いられるものの、 3次モーメント標準化関数に基づくという性格上、FM信頼性指標式 (2)と同じであるため、式(2) と原則的に同程度の精度を有すると考え られる。

式 (21)の近似式の適用範囲から TM-3 信頼性指標の適用範囲は $\left|\alpha_{3}\right|<1$ であることが分かる。式(24)では、 $\alpha_{3 G}$ が0に近付く時、TM3 信頼性指標はSM 信頼性指標に近付くことになり、式(11) の極限式 は式(24)に対しても成立する。また、 $\left|\alpha_{3 G}\right|$ が十分小さい時、式(24)を 式(25)のように展開することができる。

$$
\beta_{T M}=\beta_{S M}\left(1-\frac{1}{36} \alpha_{3 G}^{2}\right)+\frac{1}{6} \alpha_{3 G}\left(\beta_{S M}^{2}-1\right)
$$

即5、 $\left|\alpha_{36}\right|$ が十分小さい時、TM-3 信頼性指標も TM-1 信頼性指標の 形式になる。

\section{4 対数正規分布に基づく TM 信賴性指標の簡単化}

式(10) と式(17)の TM 信頼性指標は 3 つのパラメータを持つ対数 正規分布の標準正規化関数に基づいている。ここでは、式(26)に示す 対数正規分布の歪度の計算式から標準正規化関数を簡単化する。

$$
\alpha_{3 G}=\left[\exp \left(\zeta^{2}\right)+2\right] \sqrt{\exp \left(\zeta^{2}\right)-1}
$$

指数関数を級数展開することにより、らの絶対値が小さい時式(27)の 近似式が成立し、式(26)は式(28)のように表される。

$$
\begin{aligned}
& \sqrt{\exp \left(\zeta^{2}\right)-1}=\zeta \\
& \alpha_{3 G}=3 \zeta+\zeta^{3}
\end{aligned}
$$

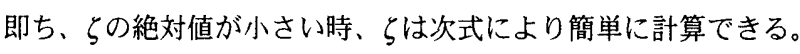

$$
\zeta=\frac{1}{3} \alpha_{3 G}
$$

従って、3つのパラメータを持つ対数正規分布の標準正規化関数は 次式のように簡潔に表される。

$$
u=\frac{\alpha_{3 G}}{6}+\frac{3}{\alpha_{3 G}} \ln \left[1+\frac{1}{3} \alpha_{3 G} x_{s}\right]
$$

式(30)により、TM 信頼性指標は次のように得られる。

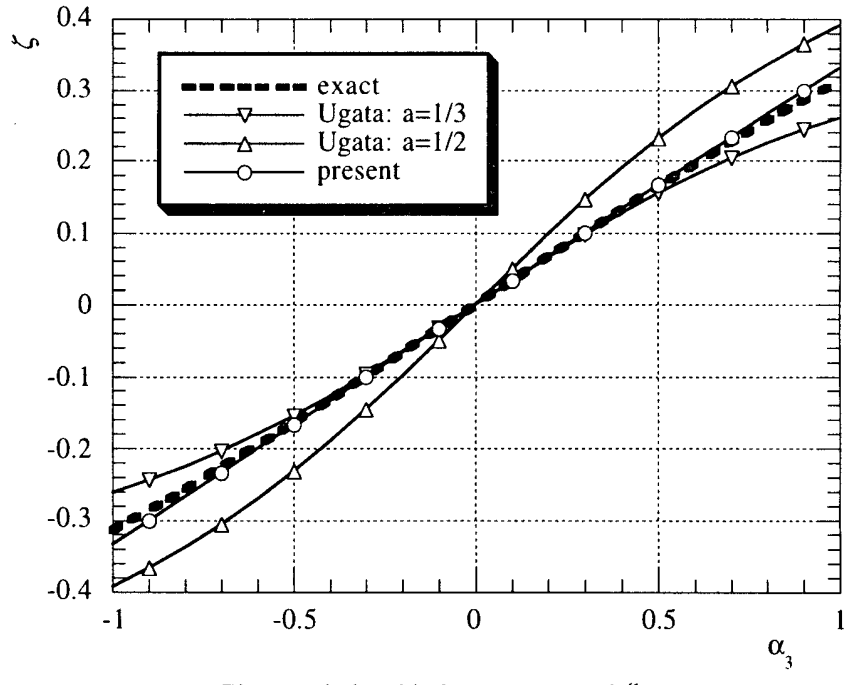

Fig. 1 Relationship between $\alpha_{3}$ and $\zeta$

$$
\beta_{T M}=-\frac{\alpha_{3 G}}{6}-\frac{3}{\alpha_{3 G}} \ln \left[1-\frac{1}{3} \alpha_{3 G} \beta_{S M}\right]
$$

以下の検討では式 (31) を TM-4 信頼性指標という。

式(29) と式(31)は式(8)と式(10)より明らかに簡単である。Fig.1に 式(8) と式(29)により得られた らの結果の比較を示す。図中の点線は 正確なら值であり、式(6)と式(7)加得られている。Fig.1により、式 (29)が簡単でありながら、 $\left|\alpha_{3 G}\right|<1$ の範囲では正確值に精度よく追従し ており、式(8)より精度がよりことが分かる。例えば $\alpha_{3 G}=0.9$ の時、正 確值 $\zeta=0.286$ に対して、式(8) と式(29)の結果はそれぞれ $0.244(a=1 /$ 2 の時、0.366) と0.3となり、相対誤差がそれぞれ $14.7 \%(a=1 / 2$ の時、 $28 \%$ ）と $4.9 \%$ となる。即ち式(29)が簡単であるものの、式(8)より精 度がよいことが分かる。しかし、 $\left|\alpha_{3 G}\right|>1$ の時、 $|\zeta|>0.314$ となり、式 (29)の近似式の前提条件として|ら斾さいことを満足しがたくなる。 従って、TM-4 信頼性指標の適用範囲を $\left|\alpha_{3 G}\right|<1$ とする。

式(31)では、 $\alpha_{3 G}$ が0に近付く時、TM-4 信頼性指標はSM 信頼性指 標に近付くことになり、式(11)の極限式は式(31)に対しても成立する。 また、 $\left|\alpha_{36}\right|$ が十分小さい時、対数関数の級数展開により式(31)を式 (1)のように展開することができる。即ち、| $\alpha_{3 G} \mid$ が十分小さい時、TM4 信頼性指標も TM-1 信頼性指標の形式になる。

\section{3. 限界状態関数の確率モーメントの求め \\ 3.1 線形和限界状態関数のモーメント}

前述の 3 次モーメント法を展開するには、限界状態関数の 3 次まで のモーメントが必要である。構造信頼性解析でよく用いられる式(32) のような線形限界状態関数については、モーメントは式(33)-(35)のよ うにを求められる。

$$
G(\mathbf{X})=\sum_{i=1}^{n} a_{i} x_{i}
$$

ただし、 $x_{i} i=1, \ldots, n$ は相互独立な確率変数であり、 $a_{i}$ は $x_{i}$ の倸数であ る。

$$
\begin{aligned}
& \mu_{G}=\sum_{i=1}^{n} a_{i} \mu_{i} \\
& \sigma_{G}^{2}=\sum_{i=1}^{n} a_{i}^{2} \sigma_{i}^{2}
\end{aligned}
$$




$$
\alpha_{3 G} \sigma_{G}^{3}=\sum_{i=1}^{n} \alpha_{3 i} a_{i}^{3} \sigma_{i}^{3}
$$

ただし、 $\mu_{G}, \sigma_{G}, \alpha_{G}$ は限界状態関数の平均值、標準偏差と歪度であり、 $\mu_{i}, \sigma_{i}, \alpha_{i}$ は確率変数 $x_{i}$ の平均値、標準偏差と歪度である。

\section{2 一般的な限界状態関数の確率モーメント}

一般的な限界状態関数 $\mathrm{Z}=G(\mathbf{X})$ に対しては標準化点推定法"1》用い

て計算する。標準化点推定法では標準正規空間で標準化推定点を求 め、各標準化推定点で Rosenblatt 逆変換により原空間の推定点を求め ることにより、限界状態関数の確率モーメントを求めている。限界状 態関数は次式のように近似されている"!!。

$$
G^{\prime}(\mathbf{X})=\sum_{i=1}^{n}\left(G_{i}-G_{\mu}\right)+G_{\mu}
$$

ただし、

$$
G_{\mu}=G(\mu), \quad G_{i}=G\left[T^{-1}\left(\mathbf{U}_{i}\right)\right]
$$

$\mathbf{U}_{i}=\left[u_{\mu 1}, u_{\mu 2}, \ldots, u_{i}, \ldots, u_{\mu n}\right]^{T} 、 \mu$ は平均值ベクトルであり、 $u_{\mu k} k=1, \ldots$, $n$ は $\mu$ に対応する $u$ 空間の第 $k$ 個目の值である。

式(37)では、 $G_{i}$ は $u_{i}$ だけの関数である。Rosenblatt変換の特性によ り、 $\mathbf{X}$ の相関性と関係なく、G メントは次式より表される。

$$
\begin{aligned}
& \mu_{G}=\sum_{i=1}^{n}\left(\mu_{i}-G_{\mu}\right)+G_{\mu} \\
& \sigma_{C}^{2}=\sum_{i=1}^{n} \sigma_{i}^{2} \\
& \alpha_{3 G} \sigma_{G}^{3}=\sum_{i=1}^{n} \alpha_{3 i} \sigma_{i}^{3}
\end{aligned}
$$

ここで $\mu_{i}, \sigma_{i} \alpha_{3 i}$ はそれぞれ $G_{i}$ の平均值、標準偏差、及び歪度である。 $G_{i}$ は $u_{i}$ だけの関数であり、 $G_{i}=g_{i}(u)$ とすると、 $\mu_{i}, \sigma_{i}, \alpha_{r i}$ は次式のように なる。

$$
\begin{aligned}
& \mu_{i}=\sum_{k=1}^{m} P_{k} g_{i}\left(u_{k}\right) \\
& \sigma_{i}^{2}=\sum_{k=1}^{m} P_{k}\left[g_{i}\left(u_{k}\right)-\mu_{i}\right]^{2} \\
& \alpha_{3 i} \sigma_{i}^{3}=\sum_{k=1}^{m} P_{k}\left[g_{i}\left(u_{k}\right)-\mu_{i}\right]^{3}
\end{aligned}
$$

ただし、 $u_{k}, P_{k}(k=1, \ldots, m)$ は標準化推定点と対応する重みである。推 定点之重みについては、 $m=3$ と $m=5$ の時の值はそれぞれ式(44) と式 (45)に示しており、任意的な $m$ に対する値は文献 [12]に与えられてい る。

3 点推定 :

$$
\begin{array}{ll}
u_{0}=0 & P_{0}=2 / 3 \\
u_{1+}=-u_{1 .}=\sqrt{3} & P_{1_{+}}=P_{1-}=1 / 6
\end{array}
$$

5 点推定 :

$$
\begin{array}{ll}
u_{0}=0 & P_{0}=8 / 15 \\
u_{1+}=-u_{1-}=1.3556 & P_{1+}=P_{1+}=0.2221 \\
u_{2+}=-u_{2-}=2.8570 & P_{2+}=P_{2-}=1.1257 \times 10^{-2}
\end{array}
$$

\section{3 分布形が分からない確率変数の取り入れ}

一般に構造信頼性解析では確率変数の分布形を用いている。しか
し、現実には全ての確率変数の分布形が既知といいがたく、分布形が 分からない確率変数を取り入れた構造信頼性解析が時には必要とな る。分布形が分からない確率変数に対してその統計データから必ず平 均値、標準偏差、歪度等のモーメントが計算でき、分布形の変わりに、 それらのモーメント值を用いて構造信頼性が解析を行うことができれ ば、分布形が分からない確率変数を取り入れることができる。

式(32)に対しては限界状態関数の 3 次までのモーメントは確率変数 の 3 次までのモーメントから簡単に計算され、分布形が分からない確 率変数を簡単に取り入れることが可能である。

一般的な限界状態関数に対しては、限界状態関数の 3 次までのモ一 メントは式(38-43) に示すように、標準化点推定法から推定され、標 準化推定点から元空間の推定点を変換するにはRosenblatt変換の逆変 換を用いている。逆Rosenblatt変換は基本的に確率変数の分布関数に よって行うが、分布形が分からない確率変数に対しては、逆Rosenblatt 変換は式(22)により、確率変数の 3 次までのモーメントを用いて行う ことができる。

\section{TM 信頼性指標の検証}

\section{14 つの TM 信頼性指標の比較}

Fig.2に TM-1, TM-2, TM-3, TM-4の 4 つの TM 信頼性指標の比較を 示す。図中、横軸は $\alpha_{3}{ }^{*} \beta_{S M}$ であり、縦軸は $\alpha_{3}=-0.2,-0.4,-0.8$ の場合の 信頼性指標の值を示す。Fig.2から次のことがわかる。

1. $\alpha_{3}{ }^{*} \beta_{S M}$ の絶対値が 1 より小さい時、4つの TM 信頼性指標はほぼ 重ねており、TM-1 信頼性指標は簡潔ながら、十分正確な結果を与え ることができる。

2. $\alpha_{3}{ }^{*} \beta_{S M}$ の絶対値が1より大きい時でも、TM-2,TM-3,TM-4の 3 つ の TM信頼性指標の間そんなに大差がないことが分かる。即ち近似的 に信頼性評価の観点から見ると、3つの TM信頼性指標は同程度の信 頼性解析結果を与えることが分かる。TM-4信頼性指標は最も簡潔で あるので、ここでは TM-4 を TM 信頼性指標として推奖する。以下の 検討では特別な場合を除き、TM-4を TM 信頼性指標という。

\section{$4.2 d R-S$ 信頼性モテル}

次式に示す簡単な限界状態関数について検討する。

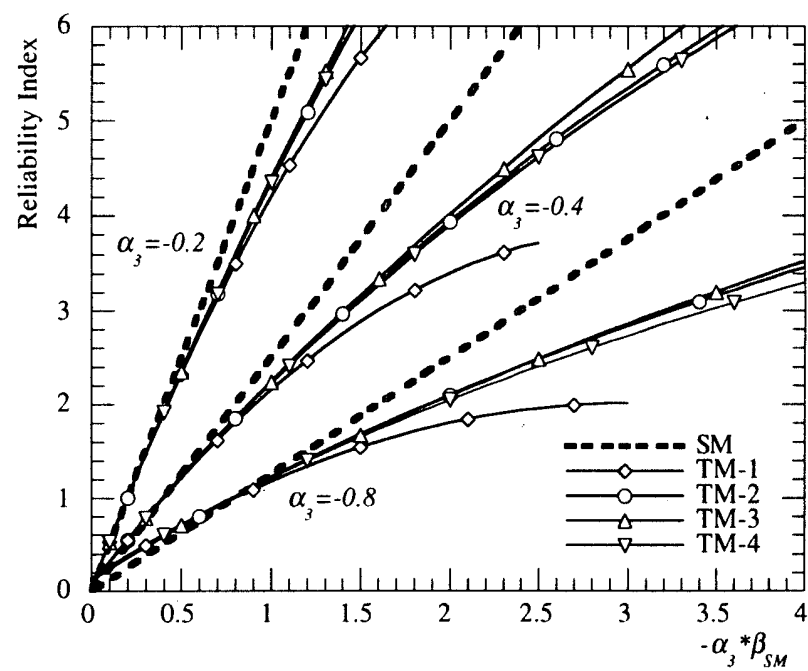

Fig. 2 Comparison of the $4 \mathrm{TM}$ reliability indices 


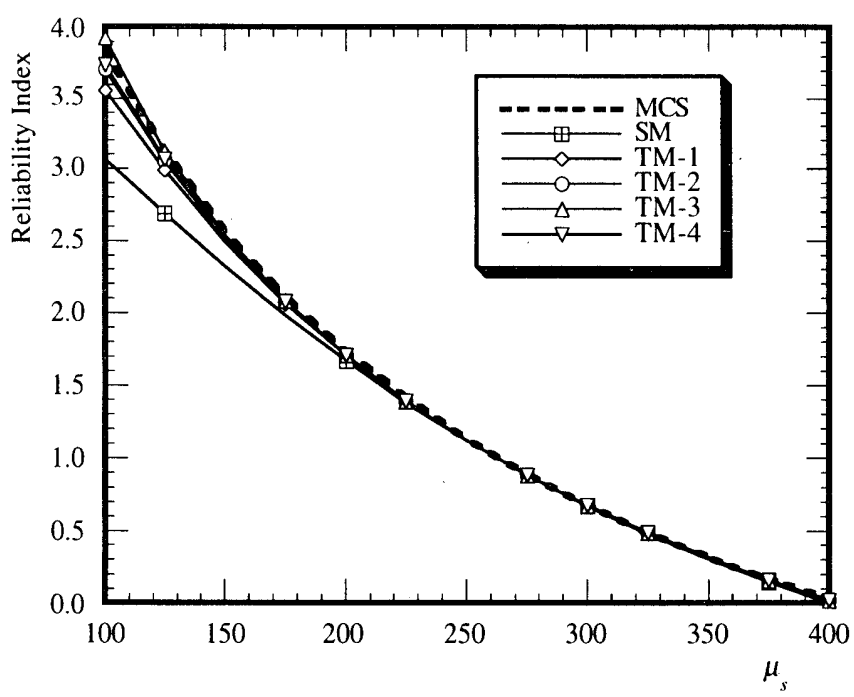

Fig.3 Reliability index for $d R-S$ reliability model

$G(\mathbf{X})=d R-S$

$R$ は抵抗力で、 $\mu_{R}=400, \sigma_{R}=80$ の対数正規分布に従い、Sは荷重で、 変動係数 0.4 の Weibull 分布に従う。d $d \mu_{d}=1, \sigma_{d}=0.1$ の正規分布を持 つRの修正係数である。

式(46)の限界状態関数は簡単であるものの、線形和ではないので、 直接式(33)-(35) を用いることができない。式(46)を式(36)で近似し、 式(36)を構成する $G_{i}$ は次のように得られる。

$$
\begin{aligned}
& G_{\mu}=\mu_{d} \mu_{R}-\mu_{s} \\
& G_{1}=d \mu_{R}-\mu_{s} \\
& G_{2}=\mu_{d} R-\mu_{s} \\
& G_{3}=\mu_{d} \mu_{R}-S
\end{aligned}
$$

式(47)の $G_{i}$ はそれぞれ $d, R, S$ の線形関数であり、式(38)-(40) を構成 する $\mu_{i} \sigma_{i} \alpha_{3 i}$ は、それぞれ $d, R, S$ の 3 次までのモーメントから容易 に得られ、式(38)-(40)により $\mu_{G}, \sigma_{G}, \alpha_{3 G}$ を容易に計算できる。Fig.3に、 信頼性指標と $S$ の平均値との関係を示す。図中、MCS の結果はサン プル数を 5,000,000 として得られたものである。Fig.3により、TM-2, TM-3, TM-4信頼性指標はMCSの結果に精度よく追従しており、3つ の TM 信頼性指標は同じ程度の値を与えていることが分かる。

\section{3 線形和限界状態関数に対する信頼性解析}

\section{次ぎの簡単な線形和限界状態関数に対して信頼性解析を行う。}

$$
G(\mathbf{X})=x_{1}+2 x_{2}+2 x_{3}+x_{4}-5 x_{5}-5 x_{6}
$$

ただし、 $x_{i}$ は相互独立な対数正規確率変数であり、平均值はそれぞれ $\mu_{1}=\ldots=\mu_{4}=120, \mu_{5}=50$ と $\mu_{6}=40$ であり、標準偏差はそれぞれ $\sigma_{1}=\ldots=\sigma_{4}=12, \sigma_{5}=15$ と $\sigma_{6}=12$ である。

式(48)はある 1 層 1 スパンラーメン構造物の破壊モードに対応して

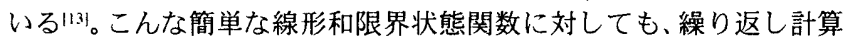
により設計点を求めなければならないことはFORM の一つの不便さ であるといえるだろう。比較するために、FORMの解析結果は信頼性 指標 $\beta_{F}=2.348\left(P_{F}=0.00943\right)$ として得られており、この問題の破壊確率 の正解值は $P_{F}=0.0121$ として得られている。

式(48)に対して、3 次モーメント法を用いて解析すれば、繰り返し 計算や設計点など全て必要とせず、非常に簡便である。 $x_{i}$ の歪度は対
数正規分布のモーメント式から $\alpha_{31}=\ldots=\alpha_{34}=0.301, \alpha_{35}=\alpha_{36}=0.927$ のよう にえられ、限界状態関数の平均值、標準偏差と歪度は式(33-35)によ りそれぞれ $\mu_{G}=270, \sigma_{G}=103.27$ と $\alpha_{3 G}=-0.5284$ のように簡単に計算され る。これらのモーメントから SM信頼性指標は $\beta_{S M}=2.6145$ のように計 算される。TM信頼性指標は $\beta_{T M}=2.2386$ として得られ、対応する破壊 確率は $P_{F}=0.0126$ である。これらの結果より、3 次モ一メシト法の計 算は簡単であるものの、この問題に対して、TM信頼性指標に対応す る破壊確率はFORM の結果より正確值に近いことが分かる。

\section{4 システム信頼性への適用}

簡単な門型 1 層 1 スパン骨組の終局耐力に関する信頼性を評価す る。システムの限界状態関数は次式で定義される。

$$
\begin{gathered}
G(\mathbf{X})=\min \left\{g_{1}(\mathbf{X}), g_{2}(\mathbf{X}), g_{3}(\mathbf{X}), g_{4}(\mathbf{X})\right\} \\
g_{1}(\mathbf{X})=2 M_{1} \quad+2 M_{3}-4.5 S \\
g_{2}(\mathbf{X})=2 M_{1}+M_{2}+M_{3}-4.5 S \\
g_{3}(\mathbf{X})=M_{1}+M_{2}+2 M_{3}-4.5 S \\
g_{4}(\mathbf{X})=M_{1}+2 M_{2}+M_{3}-4.5 S
\end{gathered}
$$

$M_{i}, S$ は相互独立的な対数正規確率変数であり、それらの平均值を それぞれと 200,50 と設定し、変動係数をそれぞれ 0.15, 0.4 と設定し た。

システム信頼性解析では、システムを構成する各限界状態関数式 (49b)-(49e)に対してFORM信頼性指標を計算し、システム信頼性とし て破壊確率の範国を評価することが通常である。3次モーメント法を 用いて解析すれば、直接式(49a)のシステムの限界状態関数のモ一メ ントを求め、繰り返し計算や設計点など必要としない。標準化 7 点推 定により限界状態関数のモーメントは $\mu_{G}=531.1, \sigma_{G}=114.4$ と $\alpha_{3 G}=-0.698$ のように計算される|2|。これらのモ一メントから SM 信頼性指標は $\beta_{S M}=4.643$ のように計算され、TM信頼性指標は $\beta_{T M}=3.264$ として得ら れる。比較するため、式(49)の限界状態関数に対して500,000点のMCS 行い、破壊確率は $5.66 \times 10^{-4}$ として得られ、対応する信頼性指標は 3.255 となる。これらの結果より、TM信頼性指標はMCSの結果と同 じ程度の値を与えていることが分かる。

\section{5 分布形が分からない確率変数を含む信頼性解析}

次ぎの限界状態関数で表される圧縮材の信頼性を評価する。

$$
G(\mathbf{X})=A x_{1} x_{2}-x_{3}
$$

ただし、Aは断面積の公称値であり、 $x_{1}$ は $A$ に含まれている不確定性 を表す確率変数である。 $x_{2}$ は降伏応力であり、 $x_{3}$ は圧縮荷重である。 圧縮材は断面が $\mathrm{H} 300 \times 200$ のS 400 鋼であり、断面積は $A=72.38 \mathrm{~cm}^{2}$ である。 $x_{1}, x_{2}$ の分布形が未知であり、統計デー夕|14|からそのモ一メ ントとして $\mu_{1}=0.990, \sigma_{1}=0.051, \alpha_{31}=0.709, \mu_{2}=3.055 \mathrm{t} / \mathrm{cm}^{2}, \sigma_{2}=0.364$, $\alpha_{32}=0.512$ が得られている。 $x_{3}$ は $\mu_{3}=100 t, \sigma_{3}=40$ の対数正規確率変数 である。

$x_{1}, x_{2}$ の分布形が未知であるものの、それらの 3 次までのモーメン 卜を用いて、4.2節と同じような方法で、限界状態関数のモーメント は $\mu_{G}=118.9, \sigma_{G}=49.1$ と $\alpha_{3 G}=-0.599$ のように容易に計算される。これら のモーメントから SM 信頼性指標は $\beta_{S M}=2.423$ のように計算され、TM 信頼性指標は $\beta_{T M}=2.076$ として得られる。比較するため、 $x_{1}, x_{2}$ の 3 次 
までのモーメントを用いて乱数を発生し ${ }^{1101}$ 、式(50)の限界状態関数 に対して 50,000点のMCS 行い、破壊確率は 0.0173 として得られ、対 応する信頼性指標は 2.112 となる。これらの結果より、TM 信頼性指 標はMCS の結果と同じ程度の值を与えていることが分かる。

\section{5. まとめ}

本論文ではいくつかの 3 次モーメント法の信頼性指標を提示、比 較、考察することにより、3 次モ一メント法の有効性を示した。本研 究で得られた結論は以下の通りである。

1. TM-1 信頼性指標は簡潔であるが、適用範囲は $\alpha_{3}{ }^{*} \beta_{S M}$ の絶対値が 1より小さい時である。

2. $\left|\alpha_{3 G}\right|$ が十分小さい時、TM-2, TM-3, TM-4の 3 つの TM信頼性指 標は全て TM-1 信頼性指標の形式で表される。

3. TM-2, TM-3, TM-4の 3 つの TM 信頼性指標の適用範囲は全て $\left|\alpha_{3 G}\right|<1$ である。

4. TM-2, TM-4 および Tichy の FOTM による TM 信頼性指標は全て 3 つのパラメータを持つ対数正規確率分布の標準正規化関数に基 づいている。

5. TM-2, TM-3, TM-4 の 3 つの TM 信頼性指標は同程度の信頼性解 析結果を与える。TM-4 信頼性指標は最も簡潔であるので、ここ では TM-4を 3 次モーメント信頼性指標として推奖する。

\section{付録：3つのパラメータを持つ対数正規確率分布の検討}

$\alpha_{3 G}>0$ の時、式(26)に示す対数正規分布の歪度の計算式と式(14)に 示す標準化境界 $u_{b}$ の 3 次方程式を比較することより、標準化境界 $u_{b}$ は次式のように表される。

$$
u_{b}=-\left[\exp \left(\zeta^{2}\right)-1\right]^{-\frac{1}{2}}
$$

式(51)を式(13)に代入することにより、 $\mathrm{A}=\exp \left(\zeta^{2}\right)$ が得られ、式(12) は次式のようになる。

$$
u=\frac{1}{\zeta} \ln \left[\sqrt{\exp \left(\zeta^{2}\right)}\left(1+x_{s} \sqrt{\exp \left(\zeta^{2}\right)-1}\right)\right]
$$

式 (52)を整理することにより、式(5)が容易に得られる。

$\alpha_{3 G}<0$ の時でも同じような結果を導くことができる。即ち、式(5)

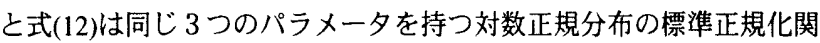
数の異なる表現形式である。

\section{参考文献}

[1] Bjerager, P. (1991). "Methods for Structural Reliability Computation." Reliability Problems: General Principles and Applications in Mechanics of Solid and Structures, ed. by F. Casciati, Springer Verlag Wien-New York, 89-136.

[2] 趋 衍剛、小野徹郎、構造信頼性解析における 3、4 次モーメント法の 考察、日本建築学会構造系論文報告集、No.530, 21-28, 2000.4 .

[3] 小野徹郎、井戸田秀樹、高次積率標準化手法の提案とそれに基づく信頼性 指標の設定、日本建築学会構造采論文報告集、No.359, 43-49, 1986.1.

[4] 小野徹郎、井戸田秀樹、高次積率標準化手法の設計法への展開とその有効 性、日本建築学会構造系論文報告集、No.365, 40-47, 1986.7.

[5] Ugata, T. and Moriyama, K. (1996), "Simple method of evaluating the failure probability of a structure considering the skewness of distribution." Nuclear Engineering and Design, 160, 307-319.

[6] 宇賀田 煡、確率分布の歪み度を考慮した信頼性解析手法一荷重係数及び 㓦力保数の簡便な評価法、日本建築学会構造系論文報告集、No.529, 43-50, 2000.3 .

[7] Tichy, M., (1994) "First-order third-moment reliability method." Structural Safety. $16,189-200$.

[8] 道 衍用、小野徹郎等、確率モーメントを用いる構造信賴性解析法、その 1 3、日本建築学会東海支部研究報告集、Vol.37. 133-144, 1999.2.

[9] Zhao, Y.G. and Ono, T., (2000). Third-moment standardization for structural reliability analysis, J. Struct. Engrg, ASCE, Vol. 126. No. 6, 724732 .

[10] Zhao, Y.G., Ono, T., Idota, H. and Hirano, T. (2001). A Three-Parameter Distribution Used for Structural Reliability Evaluation, Journal of Structural and Construction Engineering, AIJ, No.546, 31-38, 2001.8.

[11] Zhao, Y.G. and Ono, T., (2000). "New point estimates for probability moments." J. Engrg. Mech., ASCE, 126(4), 433-436.

[12] 趙 衍剛、小野徹郎、性能関数のモーメント推定、日本建築学会構造系 論文報告集、No.533, 53-60, 2000.7 .

[13] Der Kiureghian, A. and De Stefano, M., (1988). "Efficient Algorithm for SecondOrder Reliability Analysis." J. Engrg. Mech., ASCE, 117(12), 2904-2923.

[14] 小野徹郎、井戸田秀樹、高次積率を用いた䤡圧縮材及び曲げ材の抵抗強度 に関する統計論的研究、日本建築学会構造系論文報告集、No.370, 19-27, 1986.12. 